\title{
Constructions Expressing Inaccurate Quantity: Functions and Status in Modern English
}

\author{
Ludmila Petrochenko \\ Tomsk State Pedagogical University \\ Correspondence concerning this article should be addressed to Ludmila Petrochenko, Tomsk State \\ Pedagogical University, 75 Komsomolskaya Avenue, Tomsk, Russian Fedaraion, 634061. \\ E-mail: lapetrochenko@tspu.edu.ru
}

\begin{abstract}
Nina Zhukova
National Research Tomsk Polytechnic University

Correspondence concerning this article should be addressed to Nina Zhukova, National Research Tomsk Polytechnic University, 30 Lenin Avenue, Tomsk, Russian Fedaraion, 634050.E-mail: shukovans@mail.ru
\end{abstract}

\begin{abstract}
The article reviews lexical units expressing evaluative (inaccurate and/or unspecified) measurement in Modern English. The study reveals that this measurement, located on the periphery of scientific and traditional metric systems, has great significance for operational partitioning and measuring different kinds of objects in the everyday life of native English speakers. To date, there have been no detailed descriptions of lexical representations for evaluative measurement in the English language since existing papers do not approach this issue systematically. The present article, based on the British National Corpus and English dictionaries, as well as on extracts from modern American fiction, is the result of an analysis and systematization of the constructions, or patterns, expressing inaccurate and unspecified quantities in Modern English. In particular, the article provides a list of such constructions and their corresponding classifications based on their functions as specific classifiers. It also studies the structure of each type distinguished, the semantics of their components and their combinatory specificities. The analysis determines the status of these constructions in the paradigm of the category of measure in relation to the other language means of the given conceptual category, with which the constructions in question form the corresponding functional-semantic field. The results of the conducted research reveal how the "human factor" manifests itself in the English-language culture when expressing quantity evaluation of the outward things
\end{abstract}

Keywords: category of measure, inaccurate and unspecified quantity, group classifier, object measurement classifier, mensural classifier

Perhaps a definitive human characteristic is the multiplicity, the diversity and heterogeneity of forms which are used to mediate human relations with the world. Forms are human constructions, and a plurality of languages, perspectives, conceptual and mechanical schemes serve to constitute a plurality of worlds of human invention. No form or set of forms possesses a privileged logical, ontological or epistemological status over any other, and use of particular forms is more a matter of contingency, of tradition, of rhetoric, of strategy, of power and of practical implications. A particular set or fund of forms, linked over time, might be described as a 'culture', and to belong to a culture is to share knowledge of the normal use and proper practice of a fund of forms (Rapport \& Overing, 2000, p. 464).

Ethnic language is acknowledged as the base code and the foundation of each culture's semiotic system. The semantic space of culture and human consciousness is defined by the limits of expressive 
possibilities of its sign systems based on the ethnic language (Pilipenko \& Yakovenko, 1998; Gudkov, 2003; Ryabova, 2014). Identification and analysis of the possibilities of these sign systems are conducted both on the basis of different languages and on the material samples within one ethnic language. An example of the existence of different expressive possibilities in one language is the special nature of verbalization in the category of 'measure' in English.

\section{Materials and Methods}

\section{Theoretical Background}

Measure is a category that is no less important than the most general categories of thought, such as space, time, quality, quantity, motion, existence, etc. In the philosophical sense, measure expresses the dialectical unity of quality and quantity of an object (Audi, 1999; Blackburn, 2003). An understanding of measure was gradually formed in the process of the cognitive development of humanity when people began to realize that the world consists of objects that can be divided into smaller components and that such discreteness is their natural characteristic (Kleiner \& Kleiner, 1984; Bondarko, 1996).

Multiplicity and heterogeneity of objects in the real and conceptual worlds also imply a large number of possible ways for their division and, consequently, for their measurement. Units of measurement play an important role in quantification since they are the only guarantee of accuracy, which is required in modern thinking (Bondarko, 1996). Measures vary widely: precise, scientific measurement; approximative accurate measurement, not adopted in science (national measures, obsolete measures, etc.); evaluative measurement (inaccurate and/or unspecified), etc. (Nagornaya, 2005; Gupta, 2010; Petrochenko, 2014).

Names for the units of accurate measurement in English correspond to the international metric system. Cf. quantitative characteristics of space with the bodies positioned in it: measures of length, height, and width) (millimetre, centimetre, metre, kilometre, etc.); measures of area (square millimetre / centimetre / metre / kilometre, etc.); measures of capacity or volume for granular materials, liquids and other substances (cubic millimetre / centimetre / metre, millilitre, litre, etc.); body weight measures (milligram(me), gram(me), kilogram(me), tonne or metric ton, etc.) (Gupta, 2010; Hosch, 2011).

In addition to the international system, Englishspeaking countries widely use a traditional system of measures developed in the United Kingdom: measures of length, height, and width (inch, foot, yard, rod, chain, furlong, mile, league, etc.); measures of area (square inch / foot / yard / rod / mile, rood, acre, hide, etc.); measures of capacity for granular materials, liquids and other substances (cubic inch / foot / yard /, barrel, pint, quart, gallon, etc. ); body weight measures (grain, ounce, pound, stone, etc.) (Gupta, 2010; Hosch, 2011).

It is important to accurately measure quantity in scientific domains; this is achieved by using the instruments, scales and precise units of measurement. Yet, an analysis of the means of expressing quantity in everyday terms invariably leads researchers to the words and language constructions that represent approximate amounts or quantities. Such inaccurate estimations of quantities are applied to both concrete objects and substances and to the phenomena of the mental spheres expressed by abstract nouns (see Petrochenko, 2014; Zhukova, 2014; Zhukova, 2015). Thus, in many ethnic languages, including English, evaluative measurements developed over time under the influence of various socio-cultural factors along with the expression of accurate digital data since, in an ordinary consciousness, quantity is evaluated and not measured (Ryabtseva, 2005).

As the analysis of contemporary linguistic literature shows, there has been no systematic investigation of the means for representing these inaccurate (evaluative) measures in English. Evaluative measurements expressed by certain constructions were mentioned in some scientific works under the name of 'pseudo-partitives', without further concretization or a more sophisticated treatment of examples (Selkirk, 1977; Beckwith, 2007; Keizer, 2007). In the bulk of other constructions and different syntactic structures, the specific features distinguishing them from other linguistic units are less explicitly rendered and especially lack an adequate support through examples of their usage in everyday speech. Examples are not only a means of talking about something, but also a means for thinking about it (McEnery \& Hardie, 2012). To this end, the authors of the present article share their results from a detailed analysis and systematization of various constructions denoting evaluative (inaccurate and/or unspecified) measures in Modern English.

\section{Research}

This study pursues the following three goals: first, to reveal the constructions of Modern English used by English-speaking people in everyday life for a prompt division into parts and evaluation of objects of various kinds; second, to carry out an analysis and systematization of the given constructions; third, to define their status within the system of Modern English.

The investigation is specifically concerned with the constructions representing inaccurate and/or unspecified quantities $\left(\mathrm{N}^{1}\right.$ of $\mathrm{N}^{2}$; $\mathrm{N}$-sized; $\mathrm{N}^{1}+$-ful; $\mathrm{N}^{1}+$ load of $\mathrm{N}^{2}$ ) in the British and American variants 
of Modern English. To this end, the sample materials for the study were taken from the British National Corpus, from English dictionaries, and from texts of modern American popular literature. This choice was motivated by the authors' desire to show that the constructions under study which express inaccurate and unspecified quantities are often used by both Britons and Americans and belong to specific ethnocultural traits of common knowledge.

Using the data of the British corpus which are available electronically opens up considerable possibilities for collecting examples with linguistic units and constructions that represent inaccurate and unspecified quantities, while the study of American popular literarary texts with their informal language provides a way of estimating the frequency of recurrence of this linguistic phenomenon in everyday speech practices. On the whole, the eleven literary works analyzed according to a solid sampling method (about 3000 pages) yielded a large number of examples of American usages which both structurally and semantically coincide with the British ones.

The constructions in question from the literary texts, along with the examples found in the British National Corpus, were combined into three groups. The classification was carried out on the basis of structural analysis of each kind of construction, the semantics of its components, and the specific features of its combinability. For this purpose, the contextual method of analysis and the semantic interpretation method were used. Both methods require the interpretation of a linguistic element based on its context, that is, a semantically complete passage of written speech sufficient to establish the meaning of a given word or phrase (Babich, 2010).

A combination of the revealed constructions into corresponding classes was conducted on the basis of their functions as classifiers, namely, group classifiers, object measurement classifiers and mensural classifiers. For the identification of their functions along with the above-mentioned methods of contextual analysis and semantic interpretation the descriptive method and the functional analysis were used.

The functional analysis consists in distinguishing and systematizing the main and secondary functions of linguistic units representing one and the same concept; for example, the concept of measurement. Using the functions as the base, linguists divide the revealed units into those belonging to the core of the system and those constituting its periphery, thus forming the functional-semantic field (Bondarko, 1996; Rodionova, 2005).

The major focus of the investigation is the analysis of the following classifiers:

a) The group classifiers represented by the partitive construction $\mathrm{N}^{1}$ of $\mathrm{N}^{2}$ (a herd of cattle, a pack of wolves, a flock of birds, etc.). These classifiers are usually used for dividing living beings into groups with the help of collective nouns, which semantically correlate with the word 'group' (Rijkhoff, 2002; Beckwith, 2007; Payne, 2011).

b) The object measurement classifiers represented by the constructions $\mathrm{N}^{1}$ of $\mathrm{N}^{2}$, $\mathrm{N}$-sized, $\mathrm{N}^{1}+$-ful, $\mathrm{N}^{1}+$ load of $\mathrm{N}^{2}$. In the given cases, the estimation of mass, volume, size, number, etc. of different substances and objects is done with the help of improvised means ("materials at hand"): hands, palm, cups, spoons, forks, buckets, cars, buses, trucks, etc. These nouns are called container measures (Beckwith, 2007; Keizer, 2007).

c) The mensural classifiers expressed by the construction $\mathrm{N}^{1}$ of $\mathrm{N}^{2}$ (Beckwith, 2007). In this case the construction represents a part of the whole, without "materials at hand". To express the size of such parts, English has a large number of words: bit, chunk, dab, dash, dollop, drop, grain, hunk, jot, lick, mite, modicum, morsel, nugget, ounce, particle, pat, piece, rasher, scrap, sliver, smear, snippet, speck, touch, trace, whiff, etc. ( $a$ bit of land, paper; information, interest, etc.; a piece of bread, land, paper; advice, information, etc.). For these classifiers the common, generic terms of inaccurate measurement are the words 'bit' and 'piece'.

\section{Results and Discussion}

The category of measure has a complex paradigm which manifests itself in the functional-semantic field. The core of the field in English is represented by the international and traditional terms of measure, while the periphery unites a great variety of constructions, phrases, syntactic structures of evaluative (inaccurate and/or unspecified) measurement which form several zones of different status. The linguistic expression of evaluative (inaccurate and/or unspecified) measurement is located on the periphery of scientific and traditional metric systems, but it has greater importance in the operational partitioning and measuring of different kinds of objects in the everyday lives of people.

As the first step of investigation, we should mention the spatial measurement provided with the help of the objects positioned in space (stones, houses, streets, towns, galaxies). In our opinion, this measurement refers to the far peripheral zone of the functionalsemantic field. For example, to express short distances, the following words are used: stone's throw; house(s) away; store(s) away, shop(s) away:

(1) The hotel is a stone's throw from the beautiful sandy beach of Scheveningen (BYU-BNC: EBN 44)

(2) The tabby a couple of houses away on the other 
side is a cheeky sod (BYU-BNC: HJC 1).

(3) "I'm three stores away from a market," Sunny pointed out (Donally, 2013, p. 203).

(4) ... yes, unmistakably it was the same road, and he was three shops away from the toyshop (Crispin, 2007, p. 22).

Whereas, to express long distances, the phrase street(s) away is often used:

(5) ... a few seconds later I heard and saw the explosion, two or three streets away (BNC: B3F 619).

(6) There's a pub about four streets away from us where I used to go with my dad (BNC: HR9 2789).

To express vast distances, the terms town(s) away; galaxy / galaxies away are employed:

(7) burg named Little Kentucky (Adams, 2012, p. 83).

(8) They were three towns away from the Mason (BNC: HTN 174).

(9) It begins with Peter, a devoted man of faith, as he is called to the mission of a lifetime, one that takes him galaxies away from his wife, Bea (Faber, 2014, p. 386).

The investigation carried out on the basis of the information obtained from the British National Corpus, English dictionaries and texts of contemporary American popular literature gives us an idea of the linguistic units that can be included in the periphery zones. The following classifiers belong to the close periphery zone of the functional-semantic field.

In English the evaluative (inaccurate and/or unspecified) measurement has several variants, the most significant of which can be represented by the following classification:

- construction of group classifiers;

- construction of object measurement classifiers;

- construction of mensural classifiers.

Construction of group classifiers $\mathrm{N}^{1}$ of $\mathrm{N}^{2}$ (partitive construction consisting of two nouns linked together with the preposition of ) is used in partitioning of the objects of the various kinds using the words $\left(\mathrm{N}^{1}\right)$ belonging to the class of collective nouns (nouns of assemblage) (Rijkhoff, 2002, pp. 48-49; Beckwith, 2007, p. 67; Payne, 2011, p. 120).

In singular form, nouns of this class denote groups of people, living creatures, things, etc. Semantically they correlate with the neutral word 'group': cattle, deer, antelope, horse and other animals in group calculations are represented by the word herd. For example, a herd of cows (cattle), a herd of horses, a herd of deer, a herd of zebras, a herd of whales, etc.:

(10) The last time she'd met a herd of cows, she'd turned and ridden away (BYU-BNC: BOB 7).

(11) I'm planning to have a herd of deer in the parkland around the house (BYU-BNC: J54 30).

(12) When a herd of whales is sighted, two-way ra dios carry the news from village to village (BYUBNC: ABC 1).

For cattle and horses, there also exists the word drove to describe animals gathered for a cattle drive/ transportation; for example, a drove of cows (cattle) or a drove of horses:

(13) They came across at the Kershopefoot crossing of Liddel Water, driving an even larger drove of cattle from Gilsland (BYU-BNC: CD8 2).

For groups of dogs and wolves, 'in packs' is used: $a$ pack of dogs or wolves:

(14) But the cells in a pack of wolves do not have the same genes (BYU-BNC: ARR 51).

(15) The dawn light showed a crowd of men and women with a pack of dogs running beside them (BYU-BNC: AON 2).

Small livestock, such as sheep and goats, are described with the word flock, as in a flock of sheep:

(16) They stared blankly at her, like a flock of sheep startled by a tractor (BYU-BNC: FR0 22).

Birds are also categorized with the word flock, as in a flock of birds, a flock of seagulls, a flock of geese:

(17) A flock of birds passed overhead, sensing the barrenness of the space beneath them (BYUBNC: ALL 77).

(18) A girl was coming in their direction, driving $\boldsymbol{a}$ flock of geese in front of her (BYU-BNC: FUB 1).

Groups of insects are usually distinguished from the class of insects by the word swarm as in a swarm of flies; a swarm of bees:

(19) The cow was bloated and a swarm of flies were already buzzing round it (BYU-BNC: AN7 1).

(20) ... they are as furious about it as a swarm of bees (BYU-BNC: A0N 2).

Groups of fish, dolphins, whales can be separated from their class by the word school as in a school of fish, a school of sharks, a school of whales, etc.:

(21) Once dolphins locate a school of fish, they spread out ... (BYU-BNC: ABC 59).

(22) It is only the second time this century that a school of sperm whales has been seen in the waters around Orkney (BYU-BNC: K5M 20).

(23) ... and right above a school of dolphins swimming below me in the crystal-clear Pacific waters of Doubtless Bay (BYU-BNC: CAU 24).

In English, along with more commonly used words, there also exist dozens of specialist words $\left(\mathrm{N}^{1}\right)$ whose usage is even more regulated by the specific characteristics of a referent, represented by the noun $\mathrm{N}^{2}$ in the construction $\mathrm{N}^{1}$ of $\mathrm{N}^{2}$. For example, the word 'shoal' as in a shoal of fish, a shoal of herrings, a shoal of minnows, etc.:

(24) A shoal of several hundred golden-grey fish followed me (BYU-BNC: G13 8).

(25) The blue-overalled workers reacted to his passage like a shoal of minnows in the presence of a big 
fish (BYU-BNC: ANY 3).

Two other such specialist words are gaggle (a gaggle of geese) and skein (a skein of geese, a skein of crows):

(26) A dog - or better still - a gaggle of geese not only act as a deterrent to a prowler ... (BYU-BNC: ARA 33).

(27) Piper saw more choughs and, later, a skein of crows (BYU-BNC: FP7 7).

A further example of infrequent usage is pod (a pod of whales, a pod of dolphins):

(28) On Sunday there were reliable reports of a pod of live whales off Skegness (BYU-BNC: B73 2).

(29) Next day we were visited by a pod of dolphins which behaved as if they had escaped from a circus (BYU-BNC: FEP 3).

And pride (a pride of lions):

(30) A herd of deer, a pride of lions or a pack of wolves has a certain rudimentary coherence and unity of purpose (BYU-BNC: ARR 51).

Constructions of object measurement classifiers are presented in English by two most frequent types: partitive construction $\mathrm{N}^{1}$ of $\mathrm{N}^{2}$ and compound adjectives $\mathrm{N}(-)$ sized. In both cases the estimation of area, capacity and mass is done with the help of "materials at hand" (Bondarko, 1996, p. 193; Ryabtseva, 2005, p. 127; Payne, 2011, p. 116): a cup of tea, a glass of milk, a pail of cold water, a bottle of wine; a carload of tourists; a fist-sized lump of ice, a palm-sized pie, a postage-stamp-sized front garden, etc. The nouns bottle, bowl, cup, can, carton, pail, spoon, tin, truckload and others are called container measures (Beckwith, 2007, p. 29; Keizer, 2007, p. 136). The usage of one or another container measure $\mathrm{N}^{1}$ depends on the characteristics of a referent, marked as noun $\mathrm{N}^{2}$. Many nouns of this class in this construction are supplemented by the suffix - ful $\left(\mathrm{N}^{1}+\right.$-ful): a bucketful of cold water, a cupful of water to drink, a glassful of juice, a handful of coins, a jugful of water, a mouthful of sausage, a forkful of sausage, a spoonful of soup, a thimbleful of food, a shovelful of snow, etc.:

(31) Clean rocks, plastic plants, etc. in a bucket of warm water with a cupful of household bleach (BNC: CLT 563).

(32) ... he dropped it into a bucketful of warm water (BNC: AT1 201).

(33) She took out a pitcher of orange juice and poured herself a glassful (O'Callaghan, 1997, p. 59).

(34) She went directly to the cupboard and got herself a handful of crackers (Daniels, 2011, p. 214).

(35) A forkful of bacon and fried bread remained poised between plate and mouth (BNC: HHA 132).

(36) Helena Martinson took a cup and saucer, added half a spoonful of sugar, and lightened the coffee with a quick dollop of milk from the creamer (Donally, 2013, p. 96).
(37) Serve hot, warm or cold with a spoonful of olive oil and fresh lemon juice (BYU-BNC: H06 109)

(38) She gave me a penurious slice of cobbler along with a dollop of ice cream ... It was probably a good thing. By the time I had the last bite, I wasn't sure I'd be able to hold a thimbleful more of food (Beck, 2010, p. 111).

In this case, the noun semantics of measure in position $\mathrm{N}^{1}$ is not unspecified. The nouns are referred to the means expressing inaccurate quantity. People who have the experience of seeing the world around them, of interacting with it and who share the common cultural notions of objects and phenomena of this shared world are able to approximately evaluate how much fluid or any other substance a spoon, cup, jug, bucket might contain, how many coins can fit in the palm of a hand, etc.

However, under the influence of the characteristics of some referents, represented by $\mathrm{N}^{2}$, the measurement semantics in some examples becomes unspecified. For example, handful, spoonful, etc. refers to a small quantity or number:

(39) Mick was one of only a handful of people she'd met in Ireland (Connolly, 2013, p. 166).

(40) Charlotte can think of just a handful of resorts that offer the best skiing for all standards (BNC: G2W 954).

Whereas houseful, mouthful, etc. refers to a large quantity or number:

(41) ... being raised by a strong mother in a houseful of four sisters had apparently humbled him (Cates, 2013, p. 36).

(42) And yes, I am Mrs. Penelope Blakely-Jones, but it's such a mouthful I think it would be simpler if you called me Penny (Sanders, 1998, p. 301).

In other cases, the measurement semantics becomes figurative, that is, the given construction might be used as a stylistic device: a spoonful of mischief, a bucketful of pernicious politics, a bucketful of bad acting, a mouthful of decay:

(43) Last week Lord Lawson, a former chancellor, added his spoonful of mischief by blaming Mr. Major personally for last September's Black Wednesday fiasco (BNC: CR8 1638).

(44) Watch those in their full two-hour glory and you get a bucketful of pernicious politics and bad acting (BNC: ACN 525).

(45) My objection to the royal symbol is that it is dead; it is the gold filling in a mouthful of decay (BNC: ADB 56).

Such a variant of the partitive construction as $\mathrm{N}^{1}+$ load of $\mathrm{N}^{2}$ also belongs to the container measures: an armload of $N^{2}$, a carload of $N^{2}$, a cartload of $N^{2}$, a truckload of $N^{2}$, etc.:

(46) Susannah thrust an armload of empty bags at him (Bolin, 2011, p. 220). 
(47) ... a carload of American tourists pulled up in the street beside him (BNC: K2W 488).

(48) A bus rolled into town ... No classes were scheduled, but I didn't mind new busloads of tourists discovering Threadville (Bolin, 2011, p. 177).

(49) ... a collision between an engine named 'Samson' and a cartload of butter and eggs led to the use on this line of the first train whistle (BNC: B0A 1047).

(50) He drove truckloads of salt all over New England (Donally, 2013, p. 19).

In some cases the meaning of the construction $\mathrm{N}^{1}+$ load of $\mathrm{N}^{2}$ can be figurative.

(51) If I could, I would have been able to save myself a bucketload of pain over the years, most especially from my ex-husband (Beck, 2010, p. 10).

In an adjective $\mathrm{N}(-)$ sized the component, $\mathrm{N}$ acts as a mensural sample, with which the size of the other objects is compared; for example, pies the size of a palm:

(52) He greedily took the box of palm-sized pies (Beck, 2010, p. 73).

Dahlias the size of a dinner-plate:

(53) Dinner-plate-sized dahlias were clustered in a huge vase (McRae, 2010, p. 39).

An encyclopedia book the size of a coffee table:

(54) It is one of those coffee table sized encyclopedia books that contains almost anything and everything about aviation! (BYU-BNC: J1B 99);

A rock the size of a football:

(55) Rodomonte picked up a football sized rock that lay close to the entrance (BYU-BNC: FR0 221)

Bar codes the size of an elephant:

(56) ... bar codes on warehouse containers are usually 'Jumbo' sized. This is so that they are easy to find on the large boxes (BYU-BNC: C91 281);

Keys the size of a shirt button:

(57) There's no tactile feedback from the square, shirtbutton sized keys (BYU-BNC: A8E 115);

Front gardens the size of a postage-stamp:

(58) Bay windows on the ground and first floors, post age-stamp sized front gardens behind railings, nothing remotely green in-sight (BYU-BNC: CN3 216);

Pictures the size of a passport:

(59) ... it can be hidden in the palm of the hand: pills, passport sized pictures of the family (BYU-BNC: A03 247).

Constructions of mensural classifiers include the words piece, slice, chunk, hunk, slab, wedge, dollop, etc. that might be combined with many nouns (but not all of them) representing substances of hard, soft and liquid consistency. They are not container measures, since they are presenting a part of the whole object without "materials at hand" (Beckwith, 2007, p. 27). Sometimes they are called 'part nouns' (Keizer, 2007, p. 136). To express the size of such parts English has a large number of words, semantically correlating with the neutral words 'bit' and 'piece'. In everyday life large-sized parts of a hard or soft object are usually expressed with the help of the words hunk, chunk, slab (Soanes, Waite, \& Hawker, 2001; Kipfer, 2010):

- hunk (hunch): a hunk of bread, a hunk of meat;

- chunk: a chunk of ice, a chunk of mortar;

- slab: a slab of rock, a slab of steel, a slab of pizza, a slab of meat.

If necessary, it is also possible to increase the size of the part of the whole object with the same words using the corresponding attributes: a great chunk of cotton wool, a generous chunk of cheese, a huge chunk of land, a big hunk of pork, a huge hunk of bread, a huge slab of pizza, an enormous slab of cake, etc.

Measuring characteristics of the word piece expressing the common, generic term of inaccurate measure can only be identified on the basis of context.

In the following example, we are dealing with a cake cut in generous hunks. The hostess offers her guest $a$ piece of pie and also takes a sizable chunk. Thus, piece in this context corresponds to hunk and chunk:

(60) Jaymie fixed her coffee, and sat back, eyeing the generous hunks of carrot cake on a platter. "Take a piece," Dani said, grabbing a sizable chunk and a napkin for herself (Hamilton, 2013, p. 185).

In a second example, there is good reason to believe that semantically piece is equal to slice which refers to a thin flat piece of food (Summers, 1992):

(61) She smeared a dollop of pungent garlic butter on a piece of Italian bread and reached for another slice (McRae, 2010, p. 15).

In the next case, a woman decided to share with a dog a piece of crust. The description of how the dog eats the received treat includes the word morsel. Therefore, piece in this context corresponds to morsel - a very small piece of food (Summers, 1992):

(63) Taking pity on him (the dog), Anne broke off a piece of crust with a smear of cheese and laid it on the floor by her chair. He made a sudden dash to grab the morsel, then quickly retreated to chew it a couple of times and gulp it down (O’Callaghan, 1997, p. 179).

Morsel as a mensural classifier is one of the components in a long range of classifiers expressing small and very small size or measure of not only hard, soft, liquid, gaseous substances but also abstract notions. These classifiers are also widely used in the partitive construction $\mathrm{N}^{1}$ of $\mathrm{N}^{2}$ : bit, dab, dash, dollop, drop, grain, jot, lick, mite, modicum, nugget, ounce, particle, pat, rasher, scrap, smear, snippet, speck, touch, trace, whiff, etc. For these classifiers a common, generic 
term of unspecified measure is expressed by the word 'bit' (Soanes, Waite, \& Hawker, 2001; Brems, 2007; Kipfer, 2010). For example:

- $a$ bit of land, paper, baked fish; a bit of independence, interest, luck;

- a chunk of beef, bread, cheese, flesh, ice, land, gold, lead, continent; a chunk of discourse, data, information, money, time, life, etc.;

- a dash of eau-de-cologne, spice, milk, lemon juice; a dash of courage, realism, madness;

- a dollop of cream, jam, honey, ketchup, porridge, etc; a dollop of luck, confidence, gratitude, moral authority;

- a drop of blood, rain, water, wine, alcohol, fresh air; a drop of cruelty, intuition, hatred;

- a grain of dust, rice, salt, sand; a grain of truth, malice, hatred, sense;

- a mite of good wine; a mite of deception, discipline, persuasion, sentimentality;

- a modicum of accuracy, attention, encouragement, humour, luck, pocket money, success, truth;

- a morsel of bread, cheese, food, meat; a morsel of good news, support, professional advice, scandal;

- a piece of paper, land, glass, equipment; a piece of advice, information, folk wisdom;

- a scrap of paper, cloth, parchment, land; $a$ scrap of courage, positive criticism, power and majesty;

- a shred of flesh, tobacco, substance; a shred of doubt, embarrassment, evidence, proof, hope;

- a snippet of hair; a snippet of conversation, information, knowledge, English history;

- a whiff of perfume, eau de cologne, disinfectant, sea breeze, staleness; a whiff of defeat, glasnost, interest, adventure, the past, etc.

The peculiarity of the mensural classifiers is that most of them by means of the partitive construction can be combined with countable and uncountable nouns representing the objects of different classes and characteristics: discrete objects; hard, liquid, gaseous substances; soft consistency substances; phenomena of not only material but also mental and socio-cultural worlds.

\section{Conclusion}

The category of measure in the English linguistic culture has a complex paradigm. The means of its verbalization are characterized by hierarchical arrangement, which manifests itself in the existence of the functional-semantic field. The structure of this field consists of the following components: a core, zones of close and distant periphery. According to the conducted research, the core includes the words of international scientific measures and accurate traditional measures accepted in English-speaking countries. The spatial measurement and the evaluative (inaccurate and/or unspecified) measurement refer to the peripheral zones of the functional-semantic field, the full specification of which requires further analysis.

Summing up the results of this research and at the same time suggesting future strands of analysis to measure the "human factor" impact in the English language when quantifying the world, we affirm that the description of the means representing the functional-semantic field of the category of measure in English must include:

- the definition of all the zones and segments the field consists of;

- the study of the origin of its language units and the appearance of neologisms;

- the study of the peculiarities of classifiers meaning the extension and nature of their metaphorization.

\section{References}

Adams, E. (2012). Pies and prejudice. New York, NY: Berkley Prime Crime.

Audi, R. (Ed.). (1999). The Cambridge dictionary of philosophy (2nd ed.). Cambridge, UK: Cambridge University Press.

Babich, G. N. (2010). Lexicology: A current guide. Moscow, Russia: Flinta.

Beck, J. (2010). Glazed murder. New York, NY: St. Martin's Press.

Beckwith, Ch. (2007). Phoronyms. Classifiers, class nouns, and the pseudopartitive construction. New York, NY: Peter Lang Publishing.

Blackburn, S. (2003). The Oxford dictionary of philosophy. Oxford, UK: Oxford University Press.

Bolin, J. (2011). Dire threads. New York, NY: Berkley Prime Crime.

Bondarko, A. V. (Ed). (1996). Teoriya funktsional'noy grammatiki. Kachestvennost'. Kolichestvennost' [The theory of functional grammar: Quality. Quantity]. St. Petersburg, Russia: Nauka Publishing.

Brems, L. (2007). The grammaticalization of small size nouns: Reconsidering frequency and analogy. Journal of English Linguistics, 35(6), 293-324.

Brigham Young University. (n.d.). The British National Corpus (BYU-BNC). Retrieved from http://corpus. byu.edu/bnc/

Cates, B. (2013). Charms and chocolate chips. New York, NY: Berkley/NAL.

Connolly, Sh. (2013). Buried in a bog. New York, NY: Berkley Prime Crime. 
Crispin, E. (2007). The moving toyshop. London, UK: Vintage Books.

Daniels, L. (2011). Cleaning Nabokov's house. New York, NY: Touchstone Books.

Donally, C. (2013). Cat nap. New York, NY: Berkley Prime Crime.

Faber, M. (2014). The Book of strange new things. Edinburgh, UK: Canongate Books.

Gudkov, D. B. (2004). Teoriya i praktika mezhkul'turnoy kommunikatsii [The theory and practice of crosscultural communication]. Moscow, Russia: Gnosis Publishing.

Gupta, S. V. (2010). Units of measurement: Past, present and future. International system of units. Heidelberg, Germany: Springer-Verlag.

Hamilton, V. (2013). Bowled over. New York, NY: Berkley Prime Crime.

Hosch, W. L. (Ed.). (2011). The Britannica guide to numbers and measurement. New York, NY: Britannica Educational Publishing.

Keizer, E. (2007). The English noun phrase: The nature of linguistic categorization. Cambridge, UK: Cambridge University Press.

Kipfer,B.A.(Ed.).(2010). Roget's international thesaurus (7th ed.). New York, NY: Harper Collins Publishers.

Kleiner, G. M., \& Kleiner, L. M. (1984). Matematika $i$ nauchnaya kartina mira [Mathematics and the scientific picture of the world]. Kiev, USSR: Radyans'ka shkola.

McEnery, T., \& Hardie, A. (2012). Corpus linguistics: Method, theory and practice. Cambridge, UK: Cambridge University Press.

McRae, C. (2010). Lie in wait. Woodbury, MN: Midnight Ink.

Nagornaya, L. A. (2005). Antropotsentricheskiye izmereniya i sposoby ikh reprezentatsiivangliyskom yazyke [Anthropocentric measurements and the means of their representation in English]. Tomsk State Pedagogical University Bulletin, 4(48), 36-41.

O'Callaghan, M. (1997). Only in the ashes. New York, NY: Jove Books.

Payne, Th. E. (2011). Understanding English grammar: A linguistic introduction. Cambridge, UK: Cambridge University Press.

Petrochenko, L. A. (2014). Sredstva vyrazheniya malykh velichin (na primere angliyskikh sushchestvitel'nykh) [The means of expressing small quantities (English nouns used as an example)]. Tomsk State Pedagogical University Bulletin, 10(151), 29-33.

Pilipenko, A. A., \& Yakovenko, I. G. (1998). Kul'tura kak sistema [Culture as a system]. Moscow, Russia: Yazyki Russkoy Kul'tury Publishing.
Rapport, N., \& Overing, J. (2000). Social and cultural anthropology: The key concepts. London, UK: Routledge.

Rijkhoff, J. (2002). The noun phrase. Oxford, UK: Oxford University Press.

Rodionova, S. E. (2005). Semantika intensivnosti i eyo vyrazheniye $\mathrm{v}$ sovremennom russkom yazyke [Semantics of intensity and its expression means in modern Russian]. In A. V. Bondarko \& S. A. Shubik (Eds.), Problemy funktsional'noy grammatiki: Polevye struktury (pp. 150-168). St. Petersburg, Russia: Nauka Publishing.

Ryabova, M. E. (2014). Aksiologocheskiye dominanty nemetskogo i mordovskogo e'tnosov: Obshcheye i osobennoye [Axiological dominant ideas of the Mordvinian and German ethnic groups: The similarities and differences]. Tomsk Journal of Linguistics and Anthropology, 4(6), 74-77.

Ryabtseva, N. K. (2005). Yazyk i yestestvenny intellekt [Language and natural intellect]. Moscow, Russia: Akademiya Publishing.

Sanders, L. (1998). McNally's gamble. New York, NY: Berkley Books.

Selkirk, E. (1977). Some remarks on noun phrase structure. In P. W. Culicover, T. Wasow \& A Akmajian (Eds.), Formal syntax: Papers from the Conference on the formal syntax of natural language (pp. 285-316). New York, NY: Academic Press.

Soanes, C., Waite, M., \& Hawker, S. (Eds.). (2001). The Oxford dictionary, thesaurus, and wordpower guide. Oxford, UK: Oxford University Press.

Summers, D. (Ed.). (1992). Longman dictionary of English language and culture. Harlow, UK: Longman Group UK.

The British National Corpus (BNC). (n.d.) Retrieved from http://www.natcorp.ox.ac.uk

Zhukova, N. S. (2014). Leksemy so znacheniem 'glotok' $\mathrm{v}$ anglijskom, nemeckom i russkom jazykah: Osobennosti ob"ektivacii i problemy perevoda [The lexemes expressing the meaning of 'glotok' in English, Gereman, \& Russian: The peculiarities of objective representation and problems of translation]. Tomsk State Pedagogical University Bulletin, 10(151), 102-105.

Zhukova, N. S. (2015). Osobennosti ob'ektivatsii netochnogo kolichestva tverdogo veshchestva $\mathrm{v}$ russkom i angliyskom yazykakh $\mathrm{v}$ aspekte perevodcheskikh problem [The peculiarities of objective representation of an inexact measure of solids in Russian and English languages in the aspect of translation problem]. Yazyk $i$ Kul'tura, 2(30), 28-39. 